\title{
Tissue and serum immune response in chronic hepatitis C with mild histological lesions
}

\author{
AT R-Viso ${ }^{1 /+}$, MIS Duarte ${ }^{2}$, C Pagliari², ER Fernandes ${ }^{2}$, RA Brasil ${ }^{2}$, G Benard ${ }^{3}$, CC Romano ${ }^{3}$, \\ S Ogusuku3 ${ }^{3}$ NP Cavalheiro', CE Melo', AA Barone'
}

${ }^{1}$ Laboratório de Hepatite ${ }^{2}$ Laboratório de Patologia e Doenças Transmissíveis ${ }^{3}$ Laboratório de Dermatologia e Imunodeficiência, Departamento de Doenças Infecciosas e Parasitárias, Faculdade de Medicina, Universidade de São Paulo, Av. Dr. Enéas de Carvalho Aguiar 470 , Prédio II, sala 12, 0540-3000 São Paulo, SP, Brasil

The immunopathogenesis of chronic hepatitis C virus (HCV) infection is a matter of great controversy and has been suggested to involve a complex balance between cytokines with pro and anti-inflammatory activity. We investigated the expression of inflammatory cells and cytokines in the liver and serum of 51 chronically HCV infected patients and compared them to data from two sets of normal controls: 51 healthy blood donors and 33 liver biopsies of healthy liver donors. We also assessed the relationship between selected cytokines and cell populations in hepatic compartments and the disease stage. Compared with controls, hepatitis $C$ patients had a greater expression of portal $T N F-\alpha, T G F-\beta$ and $C D 4^{+}$and acinar $I F N-\gamma, T N F-\alpha, I L-1 \beta$ and $I L-4$, as well as a higher serum concentration of IL-2, $I L-10$ and TGF- $\beta$. Significant positive correlations were found between portal $C D 4^{+}$and TNF- $\alpha$, portal $C D 8^{+}$and $T G F-\beta$, portal $C D 45^{+} R O$ and $T N F-\alpha$, acinar $C D 45^{+} R O$ and IFN- $\gamma$ and acinar $C D 57^{+}$and TGF- $\beta$. In conclusion, we have shown that (i) in this sample of predominantly mild disease, the immune response was associated with a proinflammatory response pattern, (ii) $C D 4^{+} T$-lymphocytes played a major role in orchestrating the immune response and (iii) these events primarily took place in the portal space.

Key words: chronic hepatitis C - cytokines - immunohistochemistry - physiopathology of chronic hepatitis C - T-lymphocytes

Hepatitis $\mathrm{C}$ virus (HCV) is a major cause of chronic liver disease, with around 130 million people infected worldwide, accounting for an estimated $27 \%$ of cirrhosis cases and $25 \%$ of primary haepatocellular carcinoma cases (Alter 2007). Both viral and host immune mechanisms are involved in chronic infections, with the spontaneous resolution of $\mathrm{HCV}$ linked to vigorous and multi-specific T-cell responses and to attenuated $\mathrm{CD} 4^{+}$and $\mathrm{CD} 8^{+}$cell responses associated with viral persistence (Chang et al. 2001, Thimme et al. 2001, Day et al. 2002).

Several studies have suggested that T-cell immunoregulatory cytokines play a key role in both $\mathrm{HCV}$ viral persistence and in the extent of liver damage. Therefore, while some cytokines may exert a pro-inflammatory activity, such as IL-1 ( $\alpha$ and $\beta$ ), IFN- $\alpha$, IL- 8, TNF- $\alpha$ and IL-2, which can prime T-cells towards a Th-1 type immunity, others have a predominantly anti-inflammatory activity, as is the case for IL-4, IL-6 and IL-10, which are involved in Th-2 immunity. Additionally, some of these cytokines may have a fibrogenic (e.g., TGF- $\beta$ ) or an antifibrogenic (e.g., IFN- $\alpha$ ) role (Tilg et al. 2006). Currently, it is unclear whether several inflammatory processes are the result of pure Th-1 or Th-2 type responses, or, as in hepatitis C, both arms (Th1 + Th2) are involved (Brown $\&$ Neuman 2001). Nevertheless, the expression of some

Financial support: FAPESP (00/14345-0)

+ Corresponding author: ar-viso@uol.com.br

Received 28 July 2009

Accepted 21 December 2009 cytokines is more closely related to the severity of the disease. IFN- $\gamma$ is clearly augmented in the serum of chronic hepatitis C patients (Tilg et al. 1992, Cacciarelli et al. 1996, Kamal et al. 2004) and its increase has been correlated with an increase in the severity of disease (Gonzalez-Peralta et al. 1994). Moreover, an increased expression of IL-1, IL-2, IL-6, IL-10 and IL-18 has been documented in either the blood or liver of chronically HCV infected patients (Makris et al. 1994, Schvoerer et al. 2003, Hassan et al. 1997, Oyanagi et al. 1999, Polyak et al. 2001). Nonetheless, most studies have been limited by a reduced sample size, resulting in a lack of statistical power. Additionally, the great variability in the type of patients that were included in the studies, the techniques employed for cytokine assessment and the source of the specimens (peripheral blood or liver) has made it difficult to compare their results.

In this study, we aimed to investigate the immune response to $\mathrm{HCV}$ through expression of inflammatory cells and cytokines in the liver and serum of 51 chronically $\mathrm{HCV}$-infected patients compared to normal controls. We further assessed the relationship between the selected cytokines and cell populations in both the peripheral and hepatic compartments with the stage of disease.

\section{PATIENTS AND METHODS}

Patients and controls - Patients were consecutively recruited from the Infectious Diseases Division at the University Hospital from March 2001-October 2002. Most of the patients were referred from the blood bank service of the hospital. All of the patients underwent a complete medical and laboratory evaluation and a liver biopsy. The inclusion criteria for this study was as fol- 
lows: (i) an age between 18-60 years, (ii) a confirmed $\mathrm{HCV}$ infection (by a second or third-generation ELISA or immunoblot technique), (iii) a positive qualitative PCR for HCV-RNA, (iv) a 1.54-4.00 fold increase in serum alanine aminotransferase (ALT) and (v) a liver biopsy confirming chronic hepatitis, graded and staged according to Ishak et al. (1995). Patients with any other hepatic diseases, previous immunosuppressive treatment, HIV or human T cell lymphotropic virus infection, or concurrent malignant disease were excluded. Two sets of controls were selected for this study; healthy blood donors were selected for cytokine pattern comparisons and liver biopsy specimens from the organ donors were used as controls for immunohistochemistry features. The institutional review board approved the study and all of the patients and blood donors provided written informed consent.

Virological markers - Quantification of HCV-RNA was performed with an Amplicor HCV Monitor (Roche Diagnostic Systems, Mannheim, Germany) at a lower detection limit of $600 \mathrm{IU} / \mathrm{mL}$. Genotyping was carried out by using the purified product of the nested-PCR, as delimited by NCR 4 primers. The samples were submitted to sequencing (ABI Prism DNA Sequencer) using the ABI Prism Big Dye Terminator Cycle Sequencing Ready Reaction version 2.0 (Applied Biosystems). The sequences were then analysed and compared with compatible genotypes within the HCV Sequence Data Base with BLAST (Basic Local Alignment Search Tool, 2003).

Tissue sample processing - The biopsy specimens, obtained during a routine diagnosis of the patients at the University Hospital, were fixed in $10 \%$ formalin and embedded in paraffin for light microscopy. Only the biopsy specimens measuring at least $1 \mathrm{~cm}$ or bearing at least 10 portal spaces were analyzed. The specimens were then submitted to haematoxylin-eosin staining, as well as Masson's trichromate, reticulin and Perls' techniques. Two experienced histopathologists independently performed all of the analyses. The case specimens were then graded and staged according to the semi-quantitative Ishak score (Ishak et al. 1995).

Immunohistochemistry - Expression of cytokines in the biopsy specimens of HCV-cases and liver donor controls was semi-quantitatively assessed through immunomarking by immunohistochemistry, following the streptavidin-biotin-peroxidase immunohistochemical method of detection. The following specific monoclonal antibodies were employed: IFN- $\gamma$ (MAB285), TNF- $\alpha$ (AF-210-NA), IL-1 $\alpha$ (AF-200-NA), IL-1 $\beta$ (AF-201-NA), IL-2 (AF-202-NA), IL-4 (AF-204-NA), IL-6 [AF-206NA and IL-10 (MAB217) (all from R\&D Systems)] and transforming growth factor (TGF)- $\beta$ (MCA 797; SEROTEC). Cell subpopulations were assessed with the following specific monoclonal antibodies: mouse anti-CD45 ${ }^{+} \mathrm{RO}$ (M742), mouse anti-CD4 (M834), mouse anti-CD8 (M7103), mouse anti-CD68 (M876), rabbit anti-S100 (Z311) (all from DAKO) and mouse anti-CD57 (1166 CH; IMMUNOTECH).

The sections were dewaxed in xylene and hydrated through a graded ethanol series. After this, 3\% hydrogen peroxide was used to block endogenous peroxidase. The sections were incubated overnight with primary mouse antibodies and the streptavidin-biotin-peroxidase immunohistochemical method of detection was used. The Catalysed Signal Amplification-CSA, based on the peroxidase catalysed deposition of a biotinylated phenolic compound, was used to better visualise the positive cells. Biotinylated anti-mouse antibody was applied to the sample for $15 \mathrm{~min}$ at $37^{\circ} \mathrm{C}$, following application of the primary antibodies. Peroxidase-labelled streptavidin-biotin complex was then applied for $15 \mathrm{~min}$ at $37^{\circ} \mathrm{C}$, followed by the biotinyl tyramide reagent for $15 \mathrm{~min}$ and a secondary reaction with streptavidin peroxidase. The slides were counterstained with Harris haematoxylin and 3.3 diamino-benzidine tetrahydrochloride (SIGMA Chemical Company) was used as chromogen.

Counting of the cytokines and cell populations was performed with an optical microscope and a square optical grid $\left(1 \mathrm{~cm}^{2}\right)$. Screening began at the first portal space on the left upper extremity and then moved to the right and downwards, with the grid sequentially centred on each portal space and the surrounding area. Within each screening square, positive cells were counted in the portal and the periportal spaces at a 400X magnification. At least 5-10 portal spaces were counted on each slide. The number of positive cells was divided by the number of counted spaces and this result was divided by 0.0625 (Weibel 1979).

Cytokine assay - A quantitative measurement of serum cytokines was performed for the cases and blood donor controls using a commercially available enzymelinked immunosorbent assay (R\&D Systems), according to the manufacturer's instructions. The following cytokines were assessed: IL-1 $\alpha$, IL-2, IL-4, IL-6, IL8, IL-10, TNF- $\alpha$, TNF- $\beta$, IFN- $\gamma$ and TGF- $\beta$. The minimum detection limit was $10 \mathrm{pg} / \mathrm{mL}$; thus, any measures below this threshold were considered to be zero.

Statistical analysis - For descriptive analyses, the means and standard deviations, or the medians and interquartile ranges, are reported. Comparisons of proportions between the cases and controls were assessed by Chi-square test or Fisher's exact test, when appropriate. Continuous and ordinal data were compared by MannWhitney rank sum test. The Spearman's rank correlation coefficient was used to assess correlations between the continuous variables. A significance level of 0.05 was used and all of the p values are two-sided. All of the analyses were conducted in SPSS version 12 (2002).

\section{RESULTS}

Characteristics of the cases and controls - Fifty-one HCV-patients were included in the study and compared with 51 healthy blood donors and 33 liver donors. The demographic and epidemiological characteristics of the cases and controls are shown in Table I. Thirty (58.8\%) cases were male, with a median age of 38 years (range 20-59). The cases and controls did not differ significantly with regard to gender, age or race. For 41 cases, the mean disease duration from exposure to biopsy was available and was 18.2 years (range $3-31$ ). 
TABLE I

Demographic characteristics of chronically hepatitis C virus (HCV) infected cases and controls

\begin{tabular}{|c|c|c|c|}
\hline Variable & $\begin{array}{l}\text { Cases } \\
\mathrm{n}=51\end{array}$ & $\begin{array}{l}\text { Blood donors } \\
\quad \mathrm{n}=51\end{array}$ & $\begin{array}{c}\text { Liver donors } \\
n=33\end{array}$ \\
\hline Male gender - n (\%) & $30(58.8)$ & $28(54.9)$ & $15(45.5)$ \\
\hline Age years - median (range) & $38(20-59)$ & $33(18-58)$ & $36(18-60)$ \\
\hline White race - $\mathrm{n}(\%)$ & $34(66.7)$ & $36(70.6)$ & $21(63.6)$ \\
\hline \multicolumn{4}{|l|}{ Risk factors } \\
\hline History of injection drug abuse & $3(5.9)$ & NA & NA \\
\hline Previous transfusion & $21(41.2)$ & NA & NA \\
\hline Previous surgery & $27(52.9)$ & NA & NA \\
\hline Duration of $\mathrm{HCV}$ infection ${ }^{a}$ & $18.2(3-31)$ & - & - \\
\hline
\end{tabular}

$a$ : available for 41 patients and defined as time in years from suspected exposure to biopsy; NA: not available.

The detailed laboratory and histological findings of the cases are listed in Table II. In summary, the median aspartate aminotransferase and ALT levels were $45 \mathrm{IU} / \mathrm{L}$ (range 30-197) and 69 IU/L (range 32-399), respectively; 11 patients $(21.5 \%)$ had hypoalbuminaemia and 16 patients $(31.4 \%)$ had hypergammaglobulinaemia. The majority of patients $(76.5 \%)$ were infected with HCV genotype 1 and $59.2 \%$ had an HCV RNA viral load greater than $850.000 \mathrm{IU} / \mathrm{mL}$.

The median Ishak score for histology was 5 (range 3-14) and a minimal and mild disease accounted for $78.4 \%$ of the pathologic findings $(31.4 \%$ and $47.1 \%$, respectively). Confluent hepatocyte necrosis was not seen. Grade I fibrosis (F1) was seen in 30 cases (58.8\%) and portal inflammation was found in $29(56.8 \%)$ cases. All of the cases had Councilman bodies in the hepatic parenchyma and the hepatic sinusoids presented with mild hyperplasia and hypertrophy in Kupffer cells, with a predominance of lymphocyte infiltrates.

The majority (78\%) of cases showed some evidence of steatosis, which was either mild, moderate or severe, either focused or generalized and either macro or microvacuolar. Biopsies from the liver donor biopsies showed no evidence of pathologic findings. A mild haemosiderin deposition and glycogenic degeneration was seen in one and two samples, respectively.

Cytokine patterns in the cases and blood donor controls - Compared with the blood donor controls (Table III), the cases had significantly higher serum levels of IL-2 (426 \pm 362 vs. $91 \pm 124$ pg/mL; p < 0.01), IL-10 (294 \pm 289 vs. $38 \pm 141 \mathrm{pg} / \mathrm{mL}$; $\mathrm{p}<0.01)$, TNF- $\beta(17 \pm 35$ vs. 7 $\pm 11 \mathrm{pg} / \mathrm{mL} ; \mathrm{p}<0.01)$ and TGF- $\beta(898 \pm 348$ vs. $1 \pm 904$ $\mathrm{pg} / \mathrm{mL} ; \mathrm{p}<0.01)$. On the other hand, the cases showed significant lower levels of the following cytokines: IL-4 $(27 \pm 21$ vs. $62 \pm 93 \mathrm{pg} / \mathrm{mL} ; \mathrm{p}=0.02)$, IL-6 (11 \pm 30 vs. 48 $\pm 69 \mathrm{pg} / \mathrm{mL} ; \mathrm{p}<0.01)$, IL-8 (58 \pm 84 vs. $263 \pm 337 \mathrm{pg} / \mathrm{mL}$; $\mathrm{p}<0.01)$ and IFN- $\gamma(4 \pm 9$ vs. $26 \pm 73 \mathrm{pg} / \mathrm{mL} ; \mathrm{p}<0.01)$.

Cell populations and cytokine patterns in liver biopsies of the cases and liver donor controls - In immunohistochemistry reactions, the positive cytokines and cell populations were stained brown, as shown in Figs 1,2 , respectively. The cell populations from the cases had a higher expression of portal CD4 ${ }^{+}(706.4 \pm 388.0$ vs. $294.5 \pm 129.2$ cells $\left./ \mathrm{mm}^{2} ; \mathrm{p}<0.01\right)$ and $\mathrm{CD}^{+}(196.8 \pm$ 113.8 vs. $66.3 \pm 57.8$ cells $\left./ \mathrm{mm}^{2} ; \mathrm{p}<0.01\right)$ than the controls (Table IV).

The cytokine patterns of the cases had a higher expression of acinar IL-4 (2.5 \pm 2.0 vs. $1.1 \pm 1.2 \mathrm{cells} / \mathrm{mm}^{2}$; $\mathrm{p}<0.01)$, TNF- $\alpha\left(3.8 \pm 2.8\right.$ vs. $0.9 \pm 1.6$ cells $/ \mathrm{mm}^{2} ; \mathrm{p}<$ $0.01)$, IFN- $\gamma\left(3.1 \pm 5.2\right.$ vs. $1.5 \pm 2.3$ cells $\left./ \mathrm{mm}^{2} ; \mathrm{p}<0.01\right)$

\section{TABLE II}

Biochemical, virological and histological characteristics of 51 cases

\begin{tabular}{lc}
\hline Variable & $\mathrm{n}(\%)$ or median (range) \\
\hline Serum ALT (IU/L) & $88.2(32-399)$ \\
Serum AST (IU/L) & $59.3(30-197)$ \\
Total leukocytes $\left(\right.$ per $\left.\mathrm{mm}^{3}\right)$ & $6,200(3.300-13.800)$ \\
Platelets (per mm $\left.{ }^{3}\right)$ & $214,764(50.000-352.000)$ \\
Albumin (g/dL) & $4.2(2.7-5.1)$ \\
Gammaglobulin (g/dL) & $1.56(0.7-2.6)$ \\
HCV genotypes & \\
1a & $10(19.6)$ \\
1b & $29(56.8)$ \\
2a & $1(2.0)$ \\
2b & $1(2.0)$ \\
3a & $10(19.6)$ \\
Ishak score (overall) & $5(3-14)$ \\
Fibrosis stage & $1(0-6)$ \\
F1-F4 & $42(82.3)$ \\
F5-F6 & $9(17.7)$ \\
Portal inflammation & $2(0-4)$ \\
1-2 & $40(78.4)$ \\
3-4 & $11(21.6)$ \\
Periportal inflammation & $1(0-4)$ \\
0-1 & $44(86.3)$ \\
2-3 & $7(13.7)$ \\
Focal inflammation & $1(0-4)$ \\
0-1 & $47(92.2)$ \\
2 & $4(7.8)$ \\
\hline AlT alanine aminotransferse &
\end{tabular}

ALT: alanine aminotransferase; AST: aspartate aminotransferase; $\mathrm{HCV}$ : hepatitis $\mathrm{C}$ virus. 
TABLE III

Cytokine profiles in peripheral blood of chronically hepatitis $\mathrm{C}$ virus (HCV) infected cases and healthy blood donors

\begin{tabular}{lccc}
\hline & $\begin{array}{c}\text { Cases } \\
\mathrm{n}=51\end{array}$ & $\begin{array}{c}\text { Blood donors } \\
\mathrm{n}=51\end{array}$ & \\
Cytokine & mean (SD) & mean $(\mathrm{SD})$ & $\mathrm{p}$ value \\
\hline IL-2 & $426.373(361.594)$ & $90.636(123.531)$ & $<0.01$ \\
IL-10 & $294.444(289.346)$ & $37.744(140.680)$ & $<0.01$ \\
TNF- $\beta$ & $16.804(34.935)$ & $6.866(10.858)$ & $<0.01$ \\
TGF- $\beta$ & $897.553(347.819)$ & $1.334(904)$ & $<0.01$ \\
IL-1 $\alpha$ & $1.280(3.325)$ & $5.640(21.594)$ & $<0.01$ \\
IL-4 & $27.178(20.612)$ & $61.583(92.659)$ & 0.02 \\
IL-6 & $10.742(30.466)$ & $47.593(69.181)$ & $<0.01$ \\
IL-8 & $57.817(84.190)$ & $262.941(336.897)$ & $<0.01$ \\
IFN- $\gamma$ & $4.187(9.217)$ & $25.569(73.028)$ & $<0.01$ \\
TNF- $\alpha$ & $64.437(149.211)$ & $24.473(41.016)$ & 0.07
\end{tabular}

SD: standard deviations.
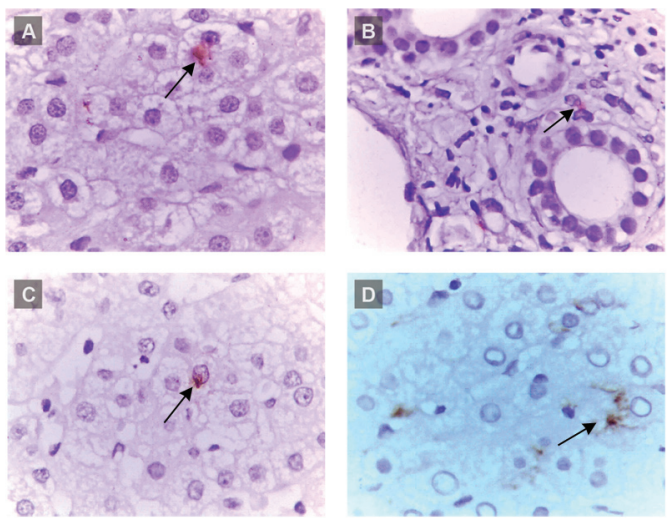

Fig. 1: typical staining of immunohistochemistry detection of cytokines: A: IFN- $\gamma$ in acinar area (400X); B: IFN $\gamma$ in portal space; C: IL2 in acinar area; D: IL6 in acinar area. Arrows indicate cells staining positive for the marker.
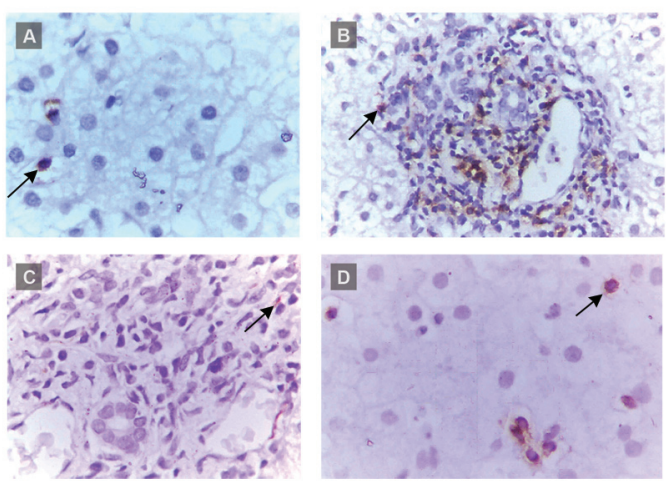

Fig. 2: typical staining of immunohistochemistry detection of cell populations. A: CD4 T-lymphocytes in acinar area (400X); B: CD4 T-lymphocytes in portal areas (200X); C: S100 cells in portal space (400X); D: CD45 cells in acinar area (400X). Arrows indicate cells staining positive for the marker.
TABLE IV

Cell populations and cytokine patterns in liver biopsy of chronically hepatitis $\mathrm{C}$ virus (HCV) infected cases and liver donors

\begin{tabular}{|c|c|c|c|}
\hline Variable & $\begin{array}{c}\text { Cases } \\
\mathrm{n}=51 \\
\text { mean (SD) }\end{array}$ & $\begin{array}{l}\text { Liver donors } \\
\qquad \mathrm{n}=33 \\
\text { mean }(\mathrm{SD})\end{array}$ & $\mathrm{p}$ value \\
\hline Portal CD45 & $412.3(290.9)$ & 304.5 (111.8) & 0.20 \\
\hline Acinar CD45 & $33.1(35.7)$ & $38.2(30.8)$ & 0.07 \\
\hline Portal CD4 & $706.4(388.0)$ & $294.5(129.2)$ & $<0.01$ \\
\hline Acinar CD4 & $46.4(33.0)$ & $36.7(23.2)$ & 0.15 \\
\hline Portal CD8 & $196.8(113.8)$ & $66.3(57.8)$ & $<0.01$ \\
\hline Acinar CD8 & $12.5(13.2)$ & $13.8(17.2)$ & 0.55 \\
\hline Portal CD68 & 107.4 (106.9) & $64.5(42.7)$ & 0.12 \\
\hline Acinar CD68 & $104.6(65.6)$ & $92.4(38.6)$ & 0.70 \\
\hline Portal S100 & $22.5(20.2)$ & $64.8(42.3)$ & $<0.01$ \\
\hline Acinar $\mathrm{S} 100$ & $2.3(4.7)$ & $8.5(7.6)$ & $<0.01$ \\
\hline Portal CD57 & $24.3(33.9)$ & $12.5(10.3)$ & 0.39 \\
\hline Acinar CD57 & $11.1(10.4)$ & $6.4(3.8)$ & 0.07 \\
\hline Portal TNF- $\alpha$ & $3.6(3.0)$ & $1.6(2.5)$ & $<0.01$ \\
\hline Acinar TNF- $\alpha$ & $3.8(2.8)$ & $0.9(1.6)$ & $<0.01$ \\
\hline Portal TGF- $\beta$ & $3.6(3.8)$ & $0.8(1.4)$ & $<0.01$ \\
\hline Acinar TGF- $\beta$ & $5.1(3.9)$ & $1.7(1.4)$ & $<0.01$ \\
\hline Portal INF- $\gamma$ & $3.1(5.2)$ & $1.5(2.3)$ & 0.14 \\
\hline Acinar INF- $\gamma$ & $2.8(2.8)$ & $0.5(1.2)$ & $<0.01$ \\
\hline Portal IL-1 $\alpha$ & 1.1 (1.9) & $0.6(1.4)$ & 0.28 \\
\hline Acinar IL-1 $\alpha$ & $0.3(0.7)$ & $0.6(2.0)$ & 0.67 \\
\hline Portal IL-1 $\beta$ & $1.3(2.6)$ & $0.7(1.2)$ & 0.74 \\
\hline Acinar IL-1 $\beta$ & $0.2(0.5)$ & $0.8(1.1)$ & $<0.01$ \\
\hline Portal IL-2 & $1.0(2.2)$ & $0.9(2.2)$ & 0.78 \\
\hline Acinar IL-2 & $1.7(1.8)$ & $1.5(2.0)$ & 0.45 \\
\hline Portal IL-4 & $1.7(2.8)$ & $0.8(1.3)$ & 0.06 \\
\hline Acinar IL-4 & $2.5(2.0)$ & $1.1(1.2)$ & $<0.01$ \\
\hline Portal IL-6 & $0.2(0.6)$ & $0.0(0.3)$ & 0.36 \\
\hline Acinar IL-6 & $0.7(1.5)$ & $0.8(1.0)$ & 0.17 \\
\hline Portal IL-10 & $0.5(1.1)$ & $0.5(1.2)$ & 0.57 \\
\hline Acinar IL-10 & $1.3(1.6)$ & $2.7(2.7)$ & $<0.01$ \\
\hline
\end{tabular}

SD: standard deviations.

and TGF- $\beta\left(5.1 \pm 3.9\right.$ vs. $1.7 \pm 1.4$ cells $\left./ \mathrm{mm}^{2} ; \mathrm{p}<0.01\right)$, compared to the controls. The cases also expressed significantly higher portal TNF- $\alpha(3.6 \pm 3.0$ vs. $1.6 \pm 2.5$ cells/ $\left.\mathrm{mm}^{2} ; \mathrm{p}<0.01\right)$ and TGF- $\beta(3.6 \pm 3.8$ vs. $0.8 \pm 1.4$ cells/ $\left.\mathrm{mm}^{2} ; \mathrm{p}<0.01\right)$ than the controls. The cases showed a significantly lower expression of portal S100 dendritic cells (DC) $\left(22.5 \pm 20.2\right.$ vs. $64.8 \pm 42.3$ cells $\left./ \mathrm{mm}^{2} ; \mathrm{p}<0.01\right)$, acinar S100 ( $2.3 \pm 4.7$ vs. $8.5 \pm 7.6$ cells $/ \mathrm{mm}^{2} ; \mathrm{p}<0.01$ ), acinar IL-1 $\beta\left(0.2 \pm 0.5\right.$ vs. $0.8 \pm 1.1$ cells $\left./ \mathrm{mm}^{2} ; \mathrm{p}<0.01\right)$ and acinar IL-10 (1.3 \pm 1.6 vs. $2.7 \pm 2.7$ cells $\left./ \mathrm{mm}^{2} ; \mathrm{p}<0.01\right)$.

Correlation patterns of cell population and cytokines among cases - The correlations between the cell markers and cytokines was analysed at either the portal spaces or the acinar areas (Table V). Significant positive correlations were seen between the following measures at the portal spaces: $\mathrm{CD} 45^{+} \mathrm{RO}$ and TNF- $\alpha, \mathrm{CD} 4^{+}$and TNF- $\alpha$, $\mathrm{CD} 8^{+}$and TGF- $\beta, \mathrm{CD} 68^{+}$and TNF- $\alpha, \mathrm{CD} 57^{+}$and IL-10, S-100 and IL-10. At the acinar level, $\mathrm{CD}^{+} 5^{+}$and IFN- $\gamma$, 
TABLE V

Correlations between cell populations and cytokine patterns by immuhohistoquemistry in liver biopsy of chronically hepatitis $\mathrm{C}$ virus (HCV) infected cases

\begin{tabular}{|c|c|c|c|c|c|c|c|}
\hline \multirow{2}{*}{$\begin{array}{l}\text { Cell } \\
\text { populations }\end{array}$} & & \multicolumn{6}{|c|}{ Citokines } \\
\hline & & Portal TNF- $\alpha$ & Acinar TNF- $\alpha$ & Portal TGF- $\beta$ & Acinar TGF- $\beta$ & Portal IFN- $\gamma$ & Acinar IFN- $\gamma$ \\
\hline \multirow[t]{2}{*}{ Portal CD45 } & rs & 0.32 & NA & 0.06 & NA & 0.08 & NA \\
\hline & $\mathrm{p}$ & $0.023^{a}$ & NA & 0.692 & NA & 0.592 & NA \\
\hline \multirow[t]{2}{*}{ Acinar CD45 } & rs & NA & 0.00 & NA & -0.08 & NA & 0.29 \\
\hline & $\mathrm{p}$ & NA & 0.992 & NA & 0.562 & NA & $0.042^{a}$ \\
\hline \multirow[t]{2}{*}{ Portal CD4 } & rs & 0.40 & NA & 0.10 & NA & 0.12 & NA \\
\hline & $\mathrm{p}$ & $0.004^{a}$ & NA & 0.496 & NA & 0.407 & NA \\
\hline \multirow[t]{2}{*}{ Acinar CD4 } & rs & NA & -0.09 & NA & 0.23 & NA & -0.17 \\
\hline & $\mathrm{p}$ & NA & 0.514 & NA & 0.107 & NA & 0.220 \\
\hline \multirow[t]{2}{*}{ Portal CD8 } & rs & 0.00 & NA & 0.30 & NA & 0.13 & NA \\
\hline & $\mathrm{p}$ & 0.994 & NA & $0.030^{a}$ & NA & 0.354 & NA \\
\hline \multirow[t]{2}{*}{ Acinar CD8 } & rs & NA & -0.06 & NA & 0.04 & NA & -0.01 \\
\hline & $\mathrm{p}$ & NA & 0.697 & NA & 0.796 & NA & 0.932 \\
\hline \multirow[t]{2}{*}{ PortalCD68 } & rs & 0.29 & NA & 0.04 & NA & 0.07 & NA \\
\hline & $\mathrm{p}$ & $0.042^{a}$ & NA & 0.797 & NA & 0.635 & NA \\
\hline \multirow[t]{2}{*}{ Acinar CD68 } & rs & NA & 0.17 & NA & 0.17 & NA & 0.20 \\
\hline & $\mathrm{p}$ & NA & 0.241 & NA & 0.227 & NA & 0.166 \\
\hline \multirow[t]{2}{*}{ Portal S100 } & rs & 0.09 & NA & -0.06 & NA & 0.04 & NA \\
\hline & $\mathrm{p}$ & 0.540 & NA & 0.689 & NA & 0.766 & NA \\
\hline \multirow[t]{2}{*}{ Acinar S100 } & rs & NA & 0.03 & NA & -0.10 & NA & 0.04 \\
\hline & $\mathrm{p}$ & NA & 0.854 & NA & 0.478 & NA & 0.768 \\
\hline \multirow[t]{2}{*}{ Portal CD57 } & rs & -0.28 & NA & 0.17 & NA & 0.06 & NA \\
\hline & $\mathrm{p}$ & $0.049^{a}$ & NA & 0.224 & NA & 0.688 & NA \\
\hline \multirow[t]{2}{*}{ Acinar CD57 } & rs & NA & -0.13 & NA & 0.29 & NA & -0.26 \\
\hline & $\mathrm{p}$ & NA & 0.358 & NA & $0.040^{a}$ & NA & 0.064 \\
\hline
\end{tabular}

$a$ : significant $\mathrm{p}$ values; NA: not applicable; rs: r-squared.

$\mathrm{CD} 45^{+}$and IL- $1 \alpha, \mathrm{CD} 57^{+}$and TGF- $\beta$ and CD $57^{+}$and IL- 2 were positively correlated, while CD68 ${ }^{+}$and IL-6 and CD68 $8^{+}$and IL-10 were negatively correlated.

The correlations between the degree of liver damage and the cell populations and cytokines were also assessed. In immunohistochemistry analyses of the cases, periportal activity was positively correlated with portal $\mathrm{CD}^{+}$expression $(\mathrm{r}=0.4 ; \mathrm{p}<0.01)$, while focal inflammation was positively correlated with acinar $\mathrm{CD}^{+}(0.33$; $\mathrm{p}=0.02$ ). A significant positive correlation for cytokine density was found between periportal hepatitis and portal IL-1 $\beta(r=0.36 ; p<0.01)$ and between acinar activity and acinar TGF- $\beta(r=0.34 ; p=0.02)$. Following a correlation analysis of the serum cytokines and the degree of liver lesions, IL-8 was positively correlated with fibrosis $(\mathrm{r}=0.29 ; \mathrm{p}=0.04)$ and IL1- $\alpha$ was negatively correlated with focal inflammation $(r=-0.29 ; \mathrm{p}=0.04)$; the other serum cytokines did not show any correlation with liver compromised liver (data not shown).

\section{DISCUSSION}

In this study, we systematically assessed the role of a comprehensive array of cytokines and cell populations in chronically $\mathrm{HCV}$ infected patients and compared them with normal controls. Among the cases, we found that there was a greater expression of portal TNF- $\alpha$, TGF- $\beta$,
$\mathrm{CD}^{+}$and $\mathrm{CD}^{+}$and acinar IFN- $\gamma$, TNF- $\alpha$, TGF- $\beta$ and IL-4, as well as a higher serum concentration of IL-2, IL-10 and TGF- $\beta$ compared to the controls.

Cytokines are key mediators of inflammation, apoptosis, necrosis and fibrosis and they are actively involved in the regeneration process of liver tissue after injury. It has been hypothesised that successful treatment of hepatitis $\mathrm{C}$ depends on a complex balance between pro and anti-inflammatory responses (Bertoletti et al. 1997, Tsai et al. 2003, Wan et al. 2009). In our study, we found both pro and anti-inflammatory responses, with a predominant pro-inflammatory response pattern in the liver mediated by IFN- $\gamma$ and TNF- $\alpha$ and modulated by $\mathrm{CD}_{4}^{+}$, $\mathrm{CD}^{+}$and $\mathrm{CD} 45 \mathrm{RO}^{+} \mathrm{T}$ lymphocytes. This complex balance is further supported by the significant correlations found between: (i) portal $\mathrm{CD}^{+}$and $\mathrm{TNF}-\alpha$, (ii) portal $\mathrm{CD} 8^{+}$and TGF- $\beta$, (ii) portal CD $45^{+} \mathrm{RO}$ and TNF- $\alpha$ and (iv) acinar $\mathrm{CD}^{-} 5^{+} \mathrm{RO}$ and IFN- $\gamma$. The latter correlations that involve $\mathrm{CD} 45^{+} \mathrm{RO}$ suggest that there is an ongoing activation of the cellular immune response, which is in agreement with the study by Murata et al. (2002).

In line with other reports (Minutello et al. 1993, Sakai et al. 1999, Exley et al. 2002), our results demonstrate the compartmentalised nature of the immune response to HCV. The correlation between periportal activity and portal $\mathrm{CD} 4^{+}$, as seen in a preliminary study (Viso et al. 
2007) and the increased expression of portal TNF- $\alpha$ and acinar IFN- $\gamma$, TNF- $\alpha$ and IL-4, which was not replicated in serum, suggests that there was an intra-hepatic response. Apparently, most of the immune response occurred at the portal space level, supported by the lack of correlation between the hepatic and serum cytokines among the cases.

TNF- $\alpha$ production is an early event in the pathogenesis of liver damage, triggering the synthesis of other cytokines. It is required for the proliferation of normal hepatocytes in liver regeneration, but it also mediates hepatocyte death (Zhu et al. 1998). The increased expression of portal and acinar TNF- $\alpha$ and acinar IFN- $\gamma$ in the cases compared to the controls reinforces the major role of these pro-inflammatory cytokines in the liver disease caused by HCV.

IL-2 is considered to be a Th1 type cytokine and is involved in enhancing the proliferation and activation of most T-lymphocytes, NK cells and B-lymphocytes. Liver sinusoidal and inflammatory cells have been reported to be sources of IL-2 and no consensus exists on the predictive value of this cytokine. Apparently, expression of IL-2 is associated with a more advanced stage of disease, as previously reported (Makris et al. 1994, Napoli et al. 1996, Bozkaya et al. 2000, Gramenzi et al. 2005). In our sample, although a higher concentration of IL-2 was found in the serum, no significant expression was found in the liver from the cases compared to the normal controls. This could possibly be due to the relatively mild disease that was observed in most of our cases, agreeing with reports from other authors (Woitas et al. 1997, Falasca et al. 2006). Indeed, it has been hypothesised that failure to secrete IL-2 might lead to a disruption of IFN- $\gamma$ and proliferative capacity, contributing to the development of a persistent infection (Semmo et al. 2005). Our findings agree with those of Gramenzi et al. (2005), who reported that there was an inverse correlation between ALT levels and IL-2 expression when cytokine profiles of patients with chronic disease were compared with patients who had persistently normal serum ALT levels.

IL-6 is a major mediator of the inflammatory process in the acute phase response, acting as a blocker of cell apoptosis (Baumann \& Gauldie 1990) and promoting the differentiation of naïve T-cells into Th1 cells. IL-6 has been associated with disease progression and has been reported to be elevated in both hepatic and peripheral compartments (Malaguarnera et al. 1997, Oyanagi et al. 1999, Lapinski et al. 2001, Falaska et al. 2006). Interestingly, in this study, IL-6 was not associated with either chronic HCV infection or with the stage of disease. Our results are in contrast to those of other researches, but agree with those of Cribier et al. (1998), who found similar patterns in serum IL-6 between HCV-infected and non-infected patients. Although, it should be noted that IL-6 was above the cut-off value in only 11 patients, possibly due to the overall lower severity of disease sample. However, these findings deserve further investigation with appropriately powered studies.

TGF- $\beta$ has been implicated as a mediator of hepatic fibrogenesis and is known to have negative regulatory effects on the immune system (Nakatsukasa et al. 1990,
Nelson et al. 1997, Roulot et al. 1999, Sakaguchi et al. 2002). In this study, expression of TGF- $\beta$ was significantly higher in both the liver (portal space and lobule) and peripheral compartments of the cases compared to the controls. These findings confirm those of other authors (Flisiak et al. 2000, Kinnman et al. 2000, Ray et al. 2003) and provide additional evidence that TGF- $\beta$ acts as an immune mediator in chronic HCV infection.

The negative correlation of S100 DC with peri-portal activity among the cases and its lower expression compared to the controls suggests that there was a lack of $\mathrm{HCV}$ recognition by these cells, which, in turn, might have facilitated viral persistence. The mechanisms involved in this down regulation are still unclear and a few hypotheses have been raised. It has been suggested that HCV proteins might modulate T-cell responses by decreasing the stimulatory ability of DC (Sarobe et al. 2003) and that there would be an allostimulatory defect of monocyte-derived DC because these cells would constitute an extra-hepatic reservoir for the virus (Bain et al. 2001). Jinushi et al. (2004) also suggested that the aberrant expression of natural killer (NK) receptors associated with chronic infection might have an impact on the magnitude and direction of DC activation of T-cells. The positive correlation between portal S100 cells and IL-10 in our study reinforces this hypothesis. IL-10 has a modulatory effect on hepatic fibrogenesis by downregulating the pro-inflammatory response, including the antigen-presenting cells and in a controlled study, IL-10 has also been shown to reduce liver damage (Nelson et al. 2000, 2003). Studies have reported that disease progression is associated with an increased expression of circulating IL-10 (Gramenzi et al. 2005), a correlation with low liver alterations (Piazzolla et al. 2000) and a decreased expression at intrahepatic compartments (Napoli et al. 1996). In our study, the cases had higher serum concentrations of IL-10, but lower intrahepatic expression, than did the respective controls, thus reinforcing the predominance of pro-inflammatory factors.

The possible correlations between the duration of infection ( $\mathrm{n}=41$ patients, whose duration of infection could be estimated) or the age of the patient $(n=51)$ with the immunological parameters was also analysed but did not reveal any biologically meaningful correlations (data not shown). The only possibly relevant finding was the observation that age was positively correlated with portal $\mathrm{CD} 45^{+} \mathrm{RO}(\mathrm{p}=0.012, \mathrm{r}=0.35)$ (as expected), as well as with acinar $\mathrm{CD}^{+}(\mathrm{p}=0.020, \mathrm{r}=0.33)$, but was negatively correlated with acinar IL-10 $(p=0.024, r=-0.32)$. Therefore, the duration of the infection or the age of the patient is unlikely to explain our findings.

Our study has some limitations. Firstly, it is possible that the observed balance towards a pro-inflammatory type of response was biased by the inclusion of cases with a milder disease; only $\sim 20 \%$ presented a more severe classification (F5-F6). For our study, we split the patients into two groups: one group containing the nine patients with severe histology (F5-F6) and the other group containing the 42 patients with mild histology (F1-F4). We then reassessed the correlation analyses of the liver data (cytokine and immunohistochemistry) 
and blood (cytokines) and we did not find any statistical differences between the two groups in any of the comparisons (data not shown). Also, the data from the 42 patients remained similar to the data from all of the patients $(\mathrm{n}=51)$ (data not shown). Secondly, the crosssectional nature of the study precludes causal inferences and a prospective assessment of these cases is warranted. However, our results devise several hypotheses for future research. Thirdly, genetic polymorphisms associated with cytokine expression have been shown to play a role in the ability to respond to therapy (Yee et al. 2001, Milton et al. 2005) and were not assessed in our study. Fourth, the function of $\mathrm{T}$ lymphocytes was not analysed in this study as it has been in other studies (Moonka et al. 2008). Finally, some comparisons might have been affected by a lack of statistical power, particularly those with a considerable floor effect that was caused by the lower limit of detection for the cytokine assays.

In conclusion, we simultaneously assessed pro and anti-inflammatory related cytokines and cell populations in the liver and sera and have shown that (i) the immune response in the samples of predominantly mild disease was associated with several pro-inflammatory cytokines, (ii) $\mathrm{CD} 4^{+} \mathrm{T}$-lymphocytes played a major role in orchestrating the immune response and (iii) these events took place primarily at the portal space. Our results suggest that this balance is highly dynamic, particularly in less severe disease and further research is needed to explore the longitudinal aspects of this relationship.

\section{REFERENCES}

Alter MJ 2007. Epidemiology of hepatitis C virus infection. World $J$ Gastroenterol 13: 2436-2441.

Bain C, Fatmi A, Zoulim F, Zarski JP, Trepo C, Inchauspe G 2001. Impaired allostimulatory function of dendritic cells in chronic hepatitis C infection. Gastroenterology 120: 512-524.

Baumann H, Gauldie J 1990. Regulation of hepatic acute phase plasma protein genes by hepatocyte stimulating factors and other mediators of inflammation. Mol Biol Med 7: 147-159.

Bertoletti A, D’Elios MM, Boni C, De Carli M, Zignego AL, Durazzo M, Missale G, Penna A, Fiaccadori F, Del Prete G, Ferrari C 1997. Different cytokine profiles of intraphepatic $\mathrm{T}$ cells in chronic hepatitis B and hepatitis C virus infections. Gastroenterology 112: 193-199.

Bozkaya H, Bozdayi AM, Aslan N, Türkay C, Sarioglu M, Cetinkaya H, Akdogan M, Cinar K, Erden E, Köse K, Sentür H, Akkiz H, Sarayalcin S, Yurdaydin C, Uzunalimoglu Ö 2000. Circulating IL-2 and IL-10 in chronic active hepatitis $\mathrm{C}$ with respect to the response to IFN treatment. Infection 28: 309-313.

Brown PMJ, Neuman MG 2001. Immunopathogenseis of hepatitis C viral infection: Th1/Th2 responses and the role of cytokines. Clin Biochemistry 34: 167-171.

Cacciarelli TV, Martinez OM, Gish RG, Villanueva JC, Krams SM 1996. Immunoregulatory cytokines in chronic hepatitis $C$ virus infection: pre- and post-treatment with interferon alfa. Hepatology 24: 6-9.

Chang KM, Thimme R, Melpolder JJ, Oldach D, Pemberton J, Moorhead-Loudis J, McHutchison JG, Alter HJ, Chisari FV 2001. Differential CD4( $\left(^{+}\right)$and $\mathrm{CD} 8\left(^{+}\right)$T-cell responsiveness in hepatitis $\mathrm{C}$ virus infection. Hepatology 33: 267-276.
Cribier B, Schmitt C, Rey D, Lang JM, Kirn A, Stoll-Keller F 1998. Production of cytokines in patients infected by hepatitis $\mathrm{C}$ virus. J Med Virol 55: 89-91.

Day CL, Lauer GM, Robbins GK, McGovern B, Wurcel AG, Gandhi RT, Chung RT, Walker BD 2002. Broad specificity of virus-specific $\mathrm{CD}^{+}{ }^{+} \mathrm{T}$-helper-cell responses in resolved hepatitis $\mathrm{C}$ virus infection. $J$ Virol 76: 12584-12595.

Exley MA, He Q, Cheng O, Wang RJ, Cheney CP, Balk SP, Koziel MJ 2002. Cutting edge: compartmentalization of Th1-like noninvariant $\mathrm{CD} 1 \mathrm{~d}-$ reactive $\mathrm{T}$ cells in hepatitis $\mathrm{C}$ virus-infected liver. J Immunol 168: 1519-1523.

Falasca K, Ucciferri C, Dalessandro M, Zingariello P, Mancino P, Petrarca C, Pizzigallo E, Conti P, Vecchiet J 2006. Cytokine patterns correlate with liver damage in patients with chronic hepatitis B and C. Ann Clin Lab Sci 36: 144-150.

Flisiak R, Pytel-Krolczuk B, Prokopowicz D 2000. Circulating transforming growth factor beta(1) as an indicator of hepatic function impairment in liver cirrhosis. Cytokine 12: 677-681.

Gonzalez-Peralta RP, Fang JW, Davis GL, Gish R, Tsukiyama-Kohara K, Kohara M, Mondelli MU, Lesniewski R, Phillips MI, Mizokami M 1994. Optimization for the detection of hepatitis C virus antigens in the liver. J Hepatol 20: 143-147.

Gramenzi A, Andreone P, Loggi E, Foschi FG, Cursaro C, Margotti M, Biselli M, Bernardi M 2005. Cytokine profile of peripheral blood mononuclear cells from patients with different outcomes of hepatitis C virus infection. J Viral Hepat 12: 525-530.

Hassan G, Moreno S, Massimi M, Di Biagio P, Stefanini S 1997. Interleukin-1-producing plasma cells in close contact with hepatocytes in patients with chronic active hepatitis. J Hepatol 27: 6-17.

Ishak K, Baptista A, Bianchi L, Callea F, De Groote J, Grudat F, Denk H, Desmet V, Korb G, MacSween RNM, Phillips MJ, Portmann BG, Poulsen H, Scheuer PJ, Schmid M, Thaler H 1995. Histological grading and staging of chronic hepatitis. J Hepatol 22: 696-699.

Jinushi M, Takehara T, Tatsumi T, Kanto T, Miyagi T, Suzuki T, Kanazawa Y, Hiramatsu N, Hayashi N 2004. Negative regulation of NK cell activities by inhibitory receptor CD94/NKG2A leads to altered NK cell-induced modulation of dendritic cell functions in chronic hepatitis C virus infection. J Immunol 173: 6072-6081.

Kamal SM, Graham CS, He Q, Bianchi L, Tawil AA, Rasenarch JW, Khalifa KA, Massoud MM, Koziel MJ 2004. Kinetics of intrahepatic hepatitis $\mathrm{C}$ virus $(\mathrm{HCV})$-specific $\mathrm{CD} 4^{+} \mathrm{T}$ cell responser in $\mathrm{HCV}$ and Schistosoma mansoni coinfection: relation to progression of liver fibrosis. J Infect Dis 189: 1140-1150.

Kinnman N, Andersson U, Hultcrantz R 2000. In situ expression of transforming growth factor-beta1-3, latent transforming growth factor-beta binding protein and tumor necrosis factor-alpha in liver tissue from patients with chronic hepatitis C. Scand J Gastroenterol 35: 1294-1300.

Lapinski TW 2001. The levels of IL-1beta, IL-4 and IL-6 in the serum and the liver tissue of chronic HCV-infected patients. Arch Immunol Ther Exp (Warsz) 49: 311-316.

Makris M, Preston FE, Ralph S 1994. Increased soluble IL-2 receptor levels in HCV-infected haemophiliacs: a possible indicator of liver disease severity. Br J Haematol 87: 419-421.

Malaguarnera M, Di Fazio I, Romeo MA, Restuccia S, Laurino A, Trovato BA 1997. Elevation of interleukin 6 levels in patients with chronic hepatitis due to hepatitis C virus. $J$ Gastroenterol 32: 211-215.

Minton EJ, Smillie D, Smith P, Shipley S, McKendrick MW, Gleeson DC, Underwood JC, Cannings C, Wilson AG, Trent Hepatitis C Study Group 2005. Clearance of hepatitis C virus is not associ- 
ated with single nucleotide polymorphisms in the IL-1, -6 or -10 genes. Hum Immunol 66: 127-132.

Minutello MA, Pileri P, Unutmaz D, Censini S, Kuo G, Houghton M, Brunetto MR, Bonino F, Abrignani S 1993. Compartmentalization of $\mathrm{T}$ lymphocytes to the site of disease: intrahepatic $\mathrm{CD}^{+} \mathrm{T}$ cells specific for the protein NS4 of hepatitis C virus in patients with chronic hepatitis C. J Exp Med 178: 17-25.

Moonka D, Milkovich KA, Rodriguez B, Abouljoud M, Lederman MM, Anthony DD 2008. Hepatitis C virus-specific T-cell gamma interferon and proliferative responses are more common in perihepatic lymph nodes than in peripheral blood or liver. J Virol 82: $11742-11748$

Murata M, Nabeshima S, Maeda N, Nakashima H, Kashiwagi S, Hayashi J 2002. Increased frequency of IFN-gamma-producing peripheral $\mathrm{CD}^{+} \mathrm{T}$ cells with memory-phenotype in patients with chronic hepatitis C. J Med Virol 67: 162-170.

Nakatsukasa H, Evarts RP, Hsia CC, Thorgeirsson SS 1990. Transforming growth factor-beta 1 and type I procollagen transcripts during regeneration and early fibrosis of rat liver. Lab Invest 63: 171-180.

Napoli J, Bishop GA, McGuinness PH, Painter DM, McCaughan GW 1996. Progressive liver injury in chronic hepatitis $\mathrm{C}$ infection correlates with increased intrahepatic expression of Th1-associated cytokines. Hepatology 24: 759-765.

Nelson DR, Gonzalez-Peralta RP, Qian K, Xu Y, Marousis CG, Davis GL, Lau JY 1997. Transforming growth factor-beta 1 in chronic hepatitis C. J Viral Hepat 4: 29-35.

Nelson DR, Lauwers GY, Lau JY, Davis GL 2000. Interleukin 10 treatment reduces fibrosis in patients with chronic hepatitis $\mathrm{C}$ : a pilot trial of interferon nonresponders. Gastroenterology 118: 655-660.

Nelson DR, Tu Z, Soldevila-Pico C, Abdelmalek M, Zhu H, Xu YL, Cabrera R, Liu C, Davis GL 2003. Long-term interleukin 10 therapy in chronic hepatitis $\mathrm{C}$ patients has a proviral and antiinflammatory effect. Hepatology 38: 859-868.

Oyanagi Y, Takahashi T, Matsui S, Takahashi S, Boku S, Takahashi K, Furukawa K, Arai F, Asakura H 1999. Enhanced expression of interleukin-6 in chronic hepatitis C. Liver 19: 464-472.

Piazzolla G, Tortorella C, Schiraldi O, Antonaci S 2000. Relationship between interferon-gamma, interleukin-10 and interleukin-12 production in chronic hepatitis $\mathrm{C}$ and in vitro effects of interferon-alpha. J Clin Immunol 20: 54-61.

Polyak SJ, Khabar KS, Rezeiq M, Gretch DR 2001. Elevated levels of interleukin-8 in serum is associated with hepatitis $\mathrm{C}$ virus infection and resistance to interferon therapy. $J$ Virol 75: 6209-6211.

Ray S, Broor SL, Vaishnav Y, Sarkar C, Girish R, Dar L, Seth P, Broor S 2003. Transforming growth factor beta in hepatitis $C$ virus infection: in vivo and in vitro findings. J Gastroenterol Hepatol 18: 393-403.

Roulot D, Sevcsik AM, Coste T, Strosberg AD, Marullo S 1999. Role of transforming growth factor beta type II receptor in hepatic fibrosis: studies of human chronic hepatitis $\mathrm{C}$ and experimental fibrosis in rats. Hepatology 29: 1730-1738.

Sakaguchi E, Kayano K, Segawa M, Okamoto M, Sakaida I, Okita $\mathrm{K}$ 2002. Th1 down-regulation at the single-lymphocyte level in HCV-related liver cirrhosis and the effect of TGF-beta on Th1 response: possible implications for the development of hepatoma. Hepatol Res 24: 282.
Sakai A, Kaneko S, Honda M, Matsushita E, Kobayashi K 1999. Quasispecies of hepatitis C virus in serum and in three different parts of the liver of patients with chronic hepatitis. Hepatology 30: 556-561.

Sarobe P, Lasarte JJ, Zabaleta A, Arribillaga L, Arina A, Melero I, Borras-Cuesta F, Prieto J 2003. Hepatitis C virus structural proteins impair dendritic cell maturation and inhibit in vivo induction of cellular immune responses. J Virol 77: 10862-10871.

Schvoerer E, Navas MC, Thumann C, Fuchs A, Meyer N, Habersetzer F, Stoll-Keller F 2003. Production of interleukin-18 and interleukin-12 in patients suffering from chronic hepatitis $\mathrm{C}$ virus infection before antiviral therapy. J Med Virol 70: 588-593.

Semmo N, Day CL, Ward SM, Lucas M, Harcourt G, Loughry A, Klenerman P 2005. Preferential loss of IL-2-secreting CD4 $4^{+}$T helper cells in chronic HCV infection. Hepatology 41: 1019-1028.

SPSS 2002. SPSS for Windows. Statistical Package for the Social Sciences, Release 12.0 ed, Chicago.

Thimme R, Oldach D, Chang KM, Steiger C, Ray SC, Chisari FV 2001. Determinants of viral clearance and persistence during acute hepatitis C virus infection. J Exp Med 194: 1395-1406.

Tilg H, Kaser A, Moschen AR 2006. How to modulate inflammatory cytokines in liver diseases. Liver Int 26: 1029-1039.

Tilg H, Wilmer A, Vogel W, Herold M, Nolchen B, Judmaier G, Huber C 1992. Serun levels of cytokynes in chronic liver diseases. Gastroenterology 103: 264-274.

Tsai SL, Sheen IS, Chien RN, Chu CM, Huang HC, Chuang YL, Lee TH, Liao SK, Lin CL, Kuo GC, Liaw YF 2003. Activation of Th1 immunity is a common immune mechanism for the successful treatment of hepatitis B and C: tetramer assay and therapeutic implications. J Biomed Sci 10: 120-135.

Viso AT, Barbosa Tde C, Yamamoto L, Pagliari C, Fernandes ER, Brasil RA, Andrade Jr HF Jr, Duarte MI, Barone AA 2007. Portal $\mathrm{CD}^{+}$and $\mathrm{CD}^{+} \mathrm{T}$ lymphocyte correlate to intensity of interface hepatitis in chronic hepatitis C. Rev Inst Med Trop Sao Paulo 49: 371-378.

Wan L, Kung YJ, Lin YJ, Liao CC, Sheu JJ, Tsai Y, Lai HC, Peng CY, Tsai FJ 2009. Th1 and Th2 cytokines are elevated in HCVinfected SVR(-) patients treated with interferon-alpha. Biochem Biophys Res Commun 379: 855-860.

Weibel ER 1979. Stereological methods. Practical methods for biological morphometry, vol. 1, Academic Press, London, 415 pp.

Woitas RP, Lechmann M, Jung G, Kaiser R, Sauerbruch T, Spengler U 1997. CD30 induction and cytokine profiles in hepatitis C virus core-specific peripheral blood T lymphocytes. J Immunol 159: 1012-1018.

Yee LJ, Tang J, Gibson AW, Kimberly R, Van Leeuwen DJ, Kaslow RA 2001. Interleukin 10 polymorphisms as predictors of sustained response in antiviral therapy for chronic hepatitis $\mathrm{C}$ infection. Hepatology 33: 708-712.

Zhu N, Khoshnan A, Schneider R, Matsumoto M, Dennert G, Ware C, Lai MM 1998. Hepatitis C virus core protein binds to the cytoplasmic domain of tumor necrosis factor (TNF) receptor 1 and enhances TNF-induced apoptosis. J Virol 72: 3691-3697. 